\title{
A POBREZA NA CONGREGAÇÃO DAS IRMÃS ESCOLARES DE NOSSA SENHORA À LUZ DE ENRIQUE DUSSEL E PAULO FREIRE
}

\author{
POVERTY IN THE CONGREGATION OF THE SCHOOL SISTERS \\ OF NOTRE DAME IN THE LIGHT OF ENRIQUE DUSSEL AND \\ PAULO FREIRE
}

\section{LA POBREZA EM LA CONGREGACIÓN DE LAS HERMANAS ESCOLARES DE NUESTRA SEÑORA A LA LUZ DE ENRIQUE DUSSEL Y PAULO FREIRE}

\author{
Mirian de Medeiros ${ }^{1}$ \\ Universidade do Extremo Sul Catarinense (UNESC), Criciúma/SC-Brasil ${ }^{1}$
}

Resumo Este artigo busca refletir sobre qual o sentido da pobreza, um dos pilares da vida religiosa católica, na Congregação das Irmãs Escolares de Nossa Senhora (IENS). A reflexão se faz a partir de Enrique Dussel, Paulo Freire e José M. Castillo. Os primeiros monges, por não aceitarem as "facilidades" da ordem social em que viviam, fugiram dela e optaram por viver na pobreza. Para Dussel, a América Latina foi "encoberta" e "inventada" à imagem da Europa, causando a opressão dos povos latinos até os dias de hoje. A alternativa para ele é uma práxis libertadora, apontando o profeta, o pobre de Iahweh, como aquele que luta pela destotalização do Sistema. Dussel vê a História como "lugar teológico", apresentando Jesus de Nazaré como a irrupção de Deus na história humana, e cuja vida se perfila aos pobres do mundo frente ao Sistema. A proposta freireana é também de práxis. Ela é luta contra a Totalização do Sistema pela educação que leva à conscientização, à reflexão e à crítica da realidade, denunciando opressões e injustiças. O profeta em ambos os autores busca frear as engrenagens que negam a pessoa viver sua condição ontológica. Os primeiros monges fugiram do Sistema. Para Dussel e Freire, precisa algo mais: negar-se a alimentá-lo como forma de oposição radical.

Palavras-chave: Pobreza; Práxis Libertadora; Destotalização do Sistema; CongregaÇão das Irmãs Escolares de Nossa Senhora (IENS). 
Abstract This article is a reflection on the meaning of poverty, one of the pillars of Catholic religious life, in the congregation of the School Sisters of Notre Dame (SSND). The reflection is from the writings of Enrique Dussel, Paulo Freire and José M. Castillo. The first monks, by not accepting the conveniences of the social order of their time, fled affluence and opted to live in poverty. For Dussel, Latin America was "covert" and "invented" in the image of Europe, causing oppression of Latin American peoples even to the present day. The alternative to it is a liberating praxis, pointing to the prophet, the poor of Yahweh, as one who struggles for the detotalisation of the system. Dussel sees history as a "theological place", presenting Jesus of Nazareth as the eruption of God in human history and whose life is portrayed to the poor of the world before the system. The Freirean proposal is also of praxis. It is a struggle against the totalization of the system by education that leads to awareness, reflection and criticism of reality, denouncing oppression and injustice. The prophet in both authors seeks to break the "gears" that deny a person to live his ontological condition. The first monks fled the System. For Dussel and Freire one needs something else: to refuse to feed oneself as a form of radical opposition.

Keywords: Poverty; Liberating Praxis; Detotalization of the System; Congregation of the School Sisters of Notre Dame (SSND).

RESUMEn Este artículo se propone a reflexionar sobre cuál es el sentido de la pobreza, uno de los pilares de la vida religiosa católica, en la Congregación de las Hermanas Educadoras de Notre Dame (HEND)/Hermanas de las Escuelas de Nuestra Señora (HENS). La reflexión se hace desde Enrique Dussel, Paulo Freire y José M. Castillo. Los primeros monjes, por no aceptar las "facilidades" del orden social en el cual vivían, huyeron de ella y optaron por vivir en la pobreza. Para Dussel, a América Latina ha sido "encubierta" e "inventada" a la imagen de Europa, causando la opresión de los pueblos latinos hasta los días de hoy. Una alternativa para él es una praxis libertadora, apuntando al profeta, al pobre de Iahveh, como aquel que lucha contra la totalización del Sistema. Dussel ve la historia como "lugar teológico", presentando a Jesús de Nazaret como una irrupción de Dios en la historia humana y cuya vida se perfila a los pobres del mundo frente al Sistema. La propuesta freireana es también de praxis. Es lucha contra la Totalización del Sistema se realiza por la educación que lleva a la concientización, a la reflexión y a la crítica de la realidad, denunciando opresiones e injusticias. El profeta en ambos autores busca frenar los engranajes que niegan a la persona vivir su condición ontológica. Los primeros monjes huyeron del sistema. Para Dussel y Freire necesita algo más: negarse a alimentarlo como forma de oposición radical. Palabras clave: Pobreza; Praxis Libertadora; Destotalización del sistema; Congregación de las Hermanas Educadoras de Notre Dame (HEND)/Hermanas de las Escuelas De Nuestra Señora. 


\section{INTRODUÇÃO}

O presente artigo visa refletir sobre como a pobreza é tratada na Congregação das Irmãs Escolares de Nossa Senhora (IENS). A situação que melhor se adéqua à reflexão a partir desta questão me remete ao modo alternativo de vida daqueles que fazem voto de Pobreza e, ao mesmo tempo, se empenham em combatê-la, lutando contra as desigualdades sociais.

A pobreza deve ser para os religiosos o fundamento de seus institutos, um estilo de vida para estes. A educação é o caminho usado por congregações religiosas para agir socialmente. As IENS declaram: A pobreza "[...] urge-os a servir os pobres [...], trabalhamos ativamente, [...] a fim de eliminar as causas fundamentais da injustiça [...]. Para que nosso confronto com a injustiça tenha crédito, nós mesmas devemos agir com justiça. Esforçamo-nos para viver na simplicidade" (VSE, 17).

Considerando a importância do processo educativo para um grande número de congregações religiosas católicas ou de outros credos religiosos, tomarei por base dois grandes pensadores que são apropriados pelo campo da educação: Enrique Dussel e Paulo Freire. Este, eminentemente um educador brasileiro, Patriarca da Educação Brasileira e referência em vários países; aquele, um filósofo argentino que escreveu, além do campo da filosofia e da ética, também nos campos da teologia e história, trazendo contribuições ao campo da educação, sendo também uma referência em diversos países.

A relação que faço entre a pobreza e o campo da educação é de duas ordens: as congregações religiosas cristãs em geral, e a IENS em específico, têm na educação de seus novos membros uma ação fundamental para atingir sua missão. ${ }^{1}$ Assim, ter claro o que entende por pobreza é fundamental na sua própria permanência. Como também, de forma mais abrangente, a ação congregacionista pode ser entendida como educativa no sentido de ação formadora das pessoas alvos de sua ação, no caso da IENS, o pobre, o excluído, o oprimido. Novamente, compreender o sentido que o pobre e a pobreza têm para a congregação é necessário para se refletir sobre sua ação concreta.

Dussel é um filósofo argentino que se empenha na busca por uma libertação dos povos; tomarei como base falas de seus primeiros anos como escritor-filósofo. Em Paulo Freire, educador brasileiro que propõe uma educação libertadora, me valerei de ideias importantes em suas obras, sobretudo, na mais conhecida delas, a Pedagogia do Oprimido, onde o autor aborda de maneira profunda as relações de opressão que assolam nossas estruturas sociais. Freire, nessa obra, aponta possibilidades de mudanças por meio de uma educação abordada de forma crítica.

Para contextualizar, me valerei de ideias de José M. Castillo, um sacerdote jesuíta espanhol que discute o futuro da Vida Religiosa Consagrada Católica na sociedade contemporânea, em sua obra O Futuro da Vida Religiosa - das origens à crise atual. No ano

\footnotetext{
As congregações religiosas católicas possuem diferentes ministérios, que significa distintos campos de atuação, mas o entendimento quanto à Missão, é de que esta é única para todos os religiosos. A Missão dos religiosos é a mesma para todos: a Missão de Cristo. As IENS escrevem: "assim, com todos os batizados, participamos da missão de Cristo que e proclamar a Boa Nova do Reino de Deus" (IENS, 1987, n. 2).
} 
de 2004, quando o livro foi escrito, Castillo problematizava a crescente saída de membros da Vida Religiosa Católica e as poucas entradas de novos membros, sinalizando que esse modelo de vida, como estava posto na época, passava por uma grande crise. Castillo iniciou seu livro com a pergunta: "Trata-se de uma crise conjuntural que, depois de alguns anos, será ultrapassada? Ou é a Vida Religiosa que vai perdendo progressivamente a sua razão de ser na Igreja e na Sociedade, de modo tal que, dentro de algum tempo, chegará a desaparecer ou ficar reduzida a grupos insignificantes? "(CASTILLO, 2004, p. 7).

Para compreendermos o significado da vida religiosa católica, é importante resgatar valores e pressupostos desse estilo de vida. Castillo remonta seu cenário da origem, na segunda metade do século III, no Egito. No século em questão, um grande número de cristãos passou a perceber a necessidade de regresso ao evangelho, sentindo-se impelido a abandonar o tipo de vida e de convivência com os demais cristãos, para fugir para o deserto e começar ali um modelo alternativo de viver a fé em Jesus Cristo. Os primeiros homens e mulheres que iniciaram essa modalidade de vida, não tomaram tal atitude por algum motivo pastoral ou projeto apostólico, e menos ainda por ideais sociais ou políticos.

Segundo Castillo (2004), o fator que mais contribuiu para o surgimento da vida dos primeiros monges foi o "afrouxamento" da vivência dos ideais do cristianismo. Aqueles que se retiraram para o deserto romperam totalmente com os valores da civilização urbana dos quais não concordavam. A influência dessas mulheres e homens na sociedade de seu tempo não foi por aquilo que fizeram, e sim por aquilo que foram.

Para o autor, é importante ressaltar a relação dos primeiros monges com os poderes públicos e econômicos de seu tempo. Eles nada pediam e nada recebiam, eram independentes da administração pública e de pessoas influentes na sociedade e também não aceitavam mendigar. Essas mulheres e homens viviam de seu próprio trabalho, não viviam de esmolas, não eram mendicantes, não dependiam economicamente de ninguém. $\mathrm{O}$ modo "extravagante" no qual viviam pelo afastamento da ordem social estabelecida era visto como uma "provocação", sendo, muitas vezes, criticados por autoridades civis e religiosas da época.

Apesar de reconhecida pela Igreja Católica, a vida religiosa não pertence a sua hierarquia. O nascimento desse modo de viver nasceu como contestação à posição católica, quando o catolicismo afastou-se dos princípios evangélicos, após a oficialização do cristianismo pelo imperador Constantino, o Grande (272-337). Constantino foi reconhecido como imperador cristão, tendo promovido inúmeras reformas político-econômicas e religiosas que concorreram para a cristianização do Império Romano e a expansão da religião cristã para diversas partes do mundo "civilizado" da época.

A contestação às comodidades do Sistema é denominada por Dussel como "profética", uma vez que denuncia opressões e injustiças sociais. Franco (2007, p. 256), ao falar da razão de ser da vida monástica em sua origem, confirma Castillo (2004), dizendo que "esta experiência marginal apresentou-se, por vezes, como reação crítica à "acomodação" [...] resultante da oficialização da religião cristã como religião de Estado [...]”. Castillo (2004) aponta a influência decisiva que teve a vida religiosa na história e na cultura ocidental.

Este artigo falará da visão de pobreza à luz do pensamento católico e seu sentido para a Congregação das Irmãs Escolares de Nossa Senhora e dessa mesma categoria para os pensadores Enrique Dussel e Paulo Freire. 


\section{A pobreza para a Igreja Católica}

A fundação da congregação das IENS não foi um fato isolado dentro da Igreja Católica, ela esteve inserida em determinado período da história da vida da igreja. Muitas outras congregações foram fundadas dentro do mesma época histórica, com objetivos similares. Para a maior parte das congregações religiosas católicas de vida ativa, fundadas a partir do século XIX, a questão da pobreza está no fundamento de tais institutos.

A partir do início do século XIX, a Vida Religiosa sofreu com os impactos das grandes mudanças sociais ocidentais e passou à fase das Congregações. Segundo Franco (2007), a Vida Religiosa foi afetada pelo iluminismo racionalista, pelo movimento político-ideológico que se inspirou no ideário da Revolução Francesa e pelo liberalismo político, entre outros.

Após a queda de Napoleão Bonaparte, na luta pela "restauração europeia", ${ }^{2}$ a educação passou a ser vista como um elemento indispensável. Nesse período, as instituições educacionais passaram a ter plena liberdade para realizar obras de caridade, como trabalhos de assistência aos pobres, em hospitais, com crianças abandonadas, deficientes físicos, entre outros. Os fundadores dessas Congregações desejavam contribuir socialmente, ajudando pobres e necessitados. De acordo com Franco (2007), aqui se deu o "boom" do Movimento Congregacionista, de onde nasceram centenas de Congregações Religiosas Católicas dedicadas ao ensino e ao cuidado dos pobres.

Segundo Cada et al. (1975 apud NELSON et al., 1979, p. 13), a adaptação da vida religiosa ocorreu de acordo com o espírito das diversas épocas e pode ser dividida em cinco estágios:

1. Época dos Padres do Deserto (200-500)

2. Época do Monaquismo (500-1200)

3. Época das Ordens Mendicantes (1200-1500)

4. Época das Ordens Apostólicas (1500-1800)

5. Época das Congregações de Ensino (1800 até o presente). ${ }^{3}$

A Congregação das IENS foi fundada no ano de 1833, na Baviera, Alemanha. Na constituição dessa congregação, podemos encontrar as razões de sua fundação: "remediar a situação social através da educação" (VSE, 1987, p. 108). Um de seus cofundadores escreveu: "A Pobreza é o fundamento do instituto" (JOB, 1833, p. 15). Dessa forma, a questão da pobreza vem desde as origens da congregação e a sua atual constituição deixa isso bem claro: "[...] afirmamos que a pobreza é o fundamento de nossa Congregação" (VSE, C. 16). A Congregação das IENS deveria atender meninas pobres, não contempladas com o atendimento em escolas e a pobreza deveria ser o fundamento e uma via de santidade para os seus membros.

2 Período entre os anos 1814 a 1848, na Europa, quando a monarquia e o clero tentaram restaurar o poder perdido após a Revolução francesa, buscando a volta do regime que fora derrubado a partir das ideias iluministas.

3 As obras de CADA et al. e Nelson et al. foram escritas nos anos de 1985 e 1979, respectivamente. Essas datas eram para eles o tempo presente. 
O século XIX foi um período em que as igrejas se empenharam em promover a educação. Por meio de instituições de ensino, era possível atingir um número bem maior de pessoas para serem cristianizadas. Um importante fato apontado pelos autores é que, de modo diferente dos séculos anteriores, no século XIX o ensino se fortificava com o "amplo papel desempenhado pelas mulheres e no valor atribuído ao serviço humilde, e devotado, prestado por pessoas que, de boa vontade e que generosamente, mergulhavam nas finalidades das instituições apostólicas (CADA et al., 1985, p. 63). A prática de atingir um grande número de pobres por meio das obras de misericórdia foi institucionalizada no século XIX. "Esse estado de coisas trouxe o inesperado benefício de dar à Igreja uma nova fonte de inspiração, graças ao exemplo de Religiosos que, vivendo pobremente, serviam aos pobres [...]" (CADA et al., 1985, p. 65).

Como já apontado, no período de luta pela "restauração europeia", a educação passou a ser vista como um elemento indispensável para o controle social. Havia dois grupos que lutavam pelo seu protagonismo: de um lado, a igreja, a monarquia e a aristocracia, e de outro, a burguesia. Nessa disputa, devido ao temor que os liberais tinham de que o ensino (católico) pudesse ser usado para defender a religião, contrariando os princípios do movimento liberal, o ensino somente foi concedido aos católicos nas escolas católicas desde que esse se apresentasse como uma tarefa de ordem moral, isto é, focado na manutenção de padrões, normas e costumes liberais, sem envolvimentos sociais e políticos, de forma a não contrariar o que estava posto na sociedade, a partir de seus dirigentes. Assim sendo, era concedida a plena liberdade aos que queriam realizar obras de caridade, como trabalhos de assistência aos pobres em hospitais, com crianças abandonadas e deficientes físicos, entre outros. $\mathrm{O}$ objetivo dessas atividades concedidas, sobretudo às igrejas, era "manter o equilíbrio e a harmonia entre os diferentes segmentos sociais, evitando assim, o perigo de conflitos e revoltas daqueles que se encontram na miséria" (SILVA, 2006, 327).

\section{A visão Latino-Americana Dusseliana}

Usando as lentes do filósofo argentino Enrique Dussel, a pobreza e as questões sociais têm raízes profundas. Dussel parte da opressão que gera a pobreza na América Latina. Ele é considerado um autor multidisciplinar, uma vez que, ao refletir sobre a libertação dos povos, faz abordagens nos campos histórico, teológico e filosófico.

O autor é considerado um dos pilares da Teologia da Libertação Latino-americana, teologia essa considerada textual e de práxis porque parte da realidade prática, que leva a uma experiência de fé produzida dentro de uma análise crítica. É uma teologia que busca as situações concretas da sociedade, apontando para uma alternativa de esperança de mudança da realidade e de libertação dos povos latino-americanos diante das opressões e injustiças sofridas desde a chegada dos primeiros colonizadores ibéricos. Dentro da Igreja. Católica, diferentes vozes denunciaram essa opressão, como Bartolomeu de las Casas, Antonio Valdivieso, Toríbio de Mogrovejo, "e outros missionários e sacerdotes que defenderam o 
direito dos oprimidos e fizeram da evangelização também um processo de promoção da vida. Apesar da dominação maciça e da contradição com o Evangelho, nunca se perderam na América Latina os sonhos de liberdade" (BOFF, L.; BOFF, C., 1985 apud Revista Digital PUC, p. 159. Citação de rodapé).

Nas primeiras obras de sua vasta produção acadêmica, ele reflete ontologicamente sobre a libertação dos povos latino-americanos, fazendo uma crítica à submissão teórica desse continente à filosofia e à epistemologia europeia, apontando para a necessidade de uma filosofia que parta da realidade latino-americana. A busca por libertação da dominação estrangeira sobre a América Latina é apontada como uma via de acesso à transformação das estruturas injustas e desumanas que marginalizam e oprimem os povos latino-americanos. $\mathrm{O}$ autor enfoca a premência de uma interpretação histórico-teológica latino-americana, remontando-a às origens do processo histórico desse continente. Dussel busca também compreender a metodologia e a ideologia dos "descobridores" e colonizadores estrangeiros, de modo a terem produzido tanta dominação, exploração, marginalização e opressão, o que resultou na colonialidade da América Latina.

Na primeira fase de seu pensamento, voltado à reflexão teológica, Dussel apresenta uma visão de modernidade diferente da visão tradicional, a qual difere do conhecimento científico europeu, considerando esse modo de ler o mundo como um mito. $\mathrm{O}$ autor questiona o conhecimento aceito de que a primeira etapa da história tida como moderna se iniciou com o mercantilismo mundial, fazendo uma distinção conceitual entre "invenção", "descobrimento", "conquista" e "colonização". A visão europeia até então aceita faz a leitura da história a partir da Europa e não a nível mundial. Conforme o autor, não houve uma história mundial até o ano de 1492, porque é essa data que dá início à operação do "sistema-mundo", quando a América Latina foi colonizada pelos europeus e suas riquezas passaram a financiar a vida europeia. Da maneira como foi muitas vezes contada a "história mundial", esta foi possível somente com a expansão marítima iniciada por Portugal nos séculos XV-XVI. "[...] com o descobrimento da América hispânica, todo o planeta se torna o "lugar" de "uma só" História Mundial [...]" (DUSSEL, 2005, p. 27).

Segundo Dussel, no tempo de Colombo, a Europa ainda não era "o centro do mundo" e Colombo tinha, acima de tudo, um desejo: chegar à Índia em busca de riquezas, indo pelo ocidente. Colombo, quando pisou nas terras caribenhas, não fez a experiência de descobrir, de ir ver a terra aonde chegara. Para ele, um experiente navegador do Atlântico, as ilhas, as plantas, os animais e os "índios" (das Índias) eram uma constatação do que já havia e que estava presente em seu imaginário, assim como no imaginário dos europeus renascentistas. Como europeu que era, fez a "invenção" do "ser-asiático" da América. Esse processo de "invenção" da América desde a visão europeia colocou a Europa no "centro" da história mundial. Quando Colombo, o representante dos reis ibéricos, chegou às terras latino-americanas, o Outro "desapareceu" porque o "Índio" não foi visto como Outro, mas como o "si-mesmo" que já era conhecido porque, para Colombo, o índio era o asiático, e então somente foi "reconhecido", negado como sendo Outro, "en-coberto". Após se ter "inventado" nosso continente, a América foi "descoberta" e inventada à imagem e semelhança da 
Europa. Os europeus recém-chegados à América pensaram e agiram como se uma cultura desconhecida para eles, tida como bruta e bárbara, devesse por eles ser civilizada. Nesse processo, foi encoberta a alteridade do homem latino-americano.

Para Dussel (1993), a América Latina não foi considerada algo "distinto", mas algo onde o europeu projetou a si mesmo à sua própria imagem e semelhança, isto é, "encobriu-a". Aqui tem origem a teoria eurocêntrica como dominação. "Descobrir", então, tornou-se sinônimo de constatar a existência de terras continentais habitadas por humanos ao oeste do Atlântico, até então absolutamente desconhecidas pelo homem europeu.

Dussel aponta para a "tese eurocêntrica", mostrando que o colonizador considerava sua cultura superior às demais culturas. Para o europeu colonizador, os povos dominados eram responsáveis por seu próprio não desenvolvimento, por isso o progresso era tão necessário para eles. Dussel nomeia esse processo como "falácia desenvolvimentista".

A dominação exercida pelos conquistadores do "Velho Mundo" foi (e ainda é) violenta e pedagógica, isto é, ensina que a sua ideia é única, inquestionável, divina (e por isso, dominadora), justificando a ação civilizadora moderna, ignorando o sofrimento das vítimas. Nesse processo, a vítima conquistada é culpada pela violência que lhe é imputada. O europeu colonizador é inocente, e sua dominação, necessária.

[...] a dominação da Europa sobre as demais culturas é uma ação pedagógica ou uma violência necessária, sendo justificada por ser uma ação civilizadora e modernizadora, e, também, pelos sofrimentos causados às pessoas de outras culturas. Esse sofrimento é visto como custo necessário ao processo civilizador a ser pago por uma "imaturidade culpável” (OLIVEIRA; DIAS, 2012, p. 94).

$\mathrm{O}$ conquistador venceu (e ainda vence) pelas armas e pela violência, impondo ao Outro (o índio, o negro, o povo, o trabalhador, o oprimido) a "verdadeira civilização" e, como fizeram os portugueses e espanhóis na América Latina, com sua religião e a divinização de seu sistema cultural.

Dussel aponta que não é possível falar sobre a história latino-americana sem trazer a presença da Igreja Católica nos primeiros séculos desta história. No mito da modernidade, o sofrimento do outro se justifica no discurso da salvação. O colonizador europeu vem para salvar os bárbaros, ensinar-lhes a verdadeira religião.

Com o colonizador hispânico e também português, a cristandade chegou a este continente, de início denominada "cristandade das Índias". Ao dizer que foi a cristandade que chegou às terras da América Latina, Dussel deixa claro que cristianismo e cristandade não podem ser tomados como sinônimos. Cristianismo é a religião cristã e cristandade é o cristianismo dentro de uma cultura. A totalidade cultural, orientada pelo cristianismo, constitui-se como cristandade. A cristandade casa-se com impérios, assume posturas políticas, econômicas, filosóficas e religiosas, dependendo dos poderes que a sustentam. Assim, podemos dizer que quem desejava atender às massas para recuperar membros perdidos com as ideias iluministas era a cristandade e não o cristianismo. 
Dando um salto no tempo, chegando ao período histórico entre os anos de 1960 a 1980, é possível perceber a chegada dos Estados Unidos e da então União Soviética como grandes potências mundiais, buscando ganhar os países para o capitalismo e o socialismo, respectivamente, a partir de uma obra expansionista econômica em direção aos países considerados periféricos e do Terceiro Mundo, na então chamada Guerra Fria. Nessa divisão, a América Latina foi alvo prioritário dos Estados Unidos, que determinava que os países latino-americanos deviam vender às nações desenvolvidas matérias-primas com preços reduzidos, produzindo um comportamento nacional manipulado pelos interesses de empresas multinacionais. Esse fora o comportamento inglês ao substituir o domínio dos luso-ibéricos na América (assim como foi na África e na Ásia). A partir desse domínio, foi reforçada a desigual distribuição da riqueza, que se concentrou nas mãos de poucos e aumentou sempre mais a desigualdade social na América Latina, com o vertiginoso crescimento da pobreza. Estava instalada uma tensão entre a libertação dos povos oprimidos da dependência imposta pelo neocolonialismo norte-americano estadunidense.

Dussel é considerado também um dos expoentes da filosofia da libertação. $\mathrm{O}$ autor traz para o centro de sua reflexão o sofrimento do Outro, do oprimido como uma realidade oculta, mantida por relações de poder assimétricas e opressivas, o que consiste na "experiência fundamental da Filosofia da Libertação, que é anterior a qualquer reflexão de cunho intelectualista e subjetivista" (OLIVEIRA; DIAS, 2012, p. 91).

A filosofia da libertação, como já colocado, diz serem os oprimidos aqueles que são exteriores ao próprio sistema que os oprime, "são partes disfuncionais da estrutura da totalidade política. São partes que devem realizar trabalhos que os alienam, que os impedem de satisfazer as necessidades que o próprio sistema produz neles" (DUSSEL, 1977, p. 75). O autor prossegue nominando os oprimidos: camponeses, classe operária trabalhadora, grupos marginalizados (boias-frias, colhedores, empregadas domésticas, mendigos...). Dussel reforça a ação de culpabilização dos oprimidos por parte dos dominadores: "os países pobres do mundo se transformam nos inimigos do centro [... que teme] as multidões demográficas mestiças, negras, amarelas" (DUSSEL, 1977, p. 78).

Na visão de Dussel, para "compreendermos" Deus, precisamos que Ele se revele a nós. Essa revelação acontece na História, pois a história concreta que vivemos cada dia é um "lugar teológico". Se não descobrirmos o sentido da História, não poderemos compreender tampouco o que Deus nos revela. Conforme Dussel, para os hebreus, ter "um ouvido aberto" é saber escutar. Moisés "ouviu”. A partir desse momento, Moisés e Deus estabeleceram um diálogo: "Moisés, Moisés! ": "Eu vi a aflição de meu povo que está no Egito, e ouvi os seus clamores por causa de seus opressores. Sim; eu conheço seus sofrimentos. [...] Vai, eu te envio ao Faraó para tirar do Egito os israelitas, meu povo" (ÊXODO, 3, 4-10).

Como alternativa para tanta dominação, Dussel propõe uma práxis libertadora, onde aponta a figura do profeta como aquele que luta pela destotalização do Sistema. Na Bíblia, o profeta é aquele que fala em nome de Deus, que denuncia injustiças. Moisés é aquele que, segundo os relatos bíblicos, foi até o Egito e libertou os hebreus que viviam sob um regime de trabalhos forçados. 
Conforme Oliveira; Dias (2012), é necessário fazer uma crítica ao sistema, buscando a transformação das causas da exclusão social. Para tanto, é necessário que se faça o reconhecimento do Outro, daquele que é vítima, não somente como diferente, mas como autônomo. Nesse caminho, é necessário estabelecer um processo de solidariedade com as vítimas. Os autores afirmam que a solidariedade compreendida por Dussel é uma atitude de responsabilidade pelo outro, colocando-se no lugar do outro.

O pensamento dusseliano, aos poucos vai se constituindo numa Ética de Libertação, incluindo todos os que estão "fora do sistema". De acordo com Alves (2005), Dussel assume uma ética de libertação marcada por quatro categorias evolutivas que vão sendo superadas por sua insuficiência ao não darem conta da realidade mutante daquele que está além do sistema, caracterizado num primeiro momento como Alteridade, depois Outro, seguidamente Pobre e Vítima. Já foi falado sobre Alteridade e Outro. A reflexão de Dussel a respeito do Pobre extrapola a esfera metafísica; para ele, a pobreza tem concretude e materialidade. A leitura de Karl Max contribuirá para a evolução do pensamento dusseliano. De acordo com Alves (2005), o pobre constitui para Dussel o objeto de sua reflexão filosófica. "Um pobre possui nome, cultura, rosto. Localizado em um continente, país, Estado, cidade, ocupando um tempo e espaço específico" (ALVES, 2005, p. 45).

Conforme Alves (2005), a partir da década de 1990, após a queda do Muro de Berlim no ano anterior, Dussel passa a focar seu pensamento na dimensão mundialidade, diante do acentuado fenômeno da globalização. O pensamento dusseliano se expande, já não considerando mais apenas a América Latina, mas passa a ter um olhar sobre todo o planeta, focando seu olhar nas "vítimas" do sistema global, vitimado pelo desequilíbrio ecológico. Dussel sinaliza a substituição da categoria pobre pela categoria vítima, no sentido de "comunidade de vítimas".

Casela (2009) acrescenta outro conceito dentro do pensamento dusseliano: o de povo. Segundo ele, para Dussel, povo são os oprimidos, as vítimas. Uma grande comunidade de vítimas que tende a alargar-se cada vez mais, em nosso mundo globalizado, tratando-o como um ator coletivo imprescindível (CASELA, 2009, p. 81).

\section{A Pedagogia Freireana}

O educador brasileiro Paulo Freire parte de uma visão análoga à de Dussel, relaciona o homem com o processo de transformação social, centrando sua reflexão em uma concepção educativa que preconiza a conscientização, a qual somente é possível na abertura à compreensão das estruturas sociais fundadas na dominação e na violência. Na forma freireana de conceber o mundo, os problemas existentes entre os homens devem ser resolvidos pelos homens dentro do tempo histórico, não num "plano superior", pois somente o homem histórico tem o poder de tornar-se senhor de sua história. Para tanto, necessita conscientizar-se da situação de opressão em que vive.

Para Freire, a educação é libertadora quando leva à leitura do mundo, denunciando toda realidade opressiva e injusta, anunciando outra realidade oposta a esta. A educação 
que liberta se posiciona em favor daqueles que "nada possuem" e vivem à margem da sociedade. O discurso freireano defende uma emancipação terrena, divergindo da visão de algumas igrejas confessionais, que apregoam que esta somente se dá no Reino dos Céus.

Para Freire, os principais problemas da educação brasileira não são pedagógicos e sim políticos. $\mathrm{O}$ autor aborda a questão da relação dialética entre opressores versus oprimidos e preconiza que é necessária uma práxis que possa orientar para uma ação que vise superar essa contradição. Freire fala de uma concepção denominada por ele como "bancária", sendo sinônima de opressão, porque nela o educador é o sujeito principal e os educandos são meros depositários, "vasilhas" a serem enchidas. O homem, como um ser de práxis, age e reflete sobre o mundo, deixando de ser um mero espectador da realidade.

Conforme Freire, a palavra tem a força de mudar o mundo, mas, para tanto, não pode estar em dicotomia com a ação, pois elas decorrem uma da outra. Existir de forma humana "é pronunciar o mundo, é modificá-lo. O mundo pronunciado, por sua vez, se volta problematizado aos sujeitos pronunciantes, a exigir deles nova pronúncia" (FREIRE, 2014, p. 108). Para que essa pronúncia possa acontecer, o diálogo é pressuposto.

Segundo a visão freirena, é preciso que o homem "leia o mundo" e essa leitura se dá na sua experiência existencial e lhe dá a capacidade de "escrevê-lo" ou de "reescrevê-lo" "[...] de transformá-lo através de nossa prática consciente" (FREIRE, 2001, p. 20).

Para Freire, a educação não é um ato neutro. Para o autor, "é tão impossível negar a natureza política do processo educativo quanto negar o caráter educativo do ato político" (FREIRE, 2001, p. 23). A educação enquanto um ato político nos remete à reflexão: " $a$ favor de quem e do quê, portanto contra quem e contra o quê, fazemos a educação e de $a$ favor de quem e do quê, portanto contra quem e contra o quê, desenvolvemos a atividade política" (FREIRE, 2001, p. 23; grifos do original).

Trazer clareza à realidade, fazendo que o homem tome uma posição crítica diante da realidade em que vive, pode ser considerado como algo absurdo e demoníaco. Sujeitos inquietos, criadores, avessos à coisificação são tidos como rebeldes. O homem consciente de que pode transformar o mundo torna-se um ser de práxis, passando a ver-se como um ser histórico e, assim, pode tirar o véu que encobre a realidade e a transforma em mito.

Para Freire, os resultados da conscientização possibilitam que os homens se insiram como sujeitos dentro da História. Para Weffort (1995 apud FREIRE 2014), a tomada de consciência abre caminho à expressão de insatisfações sociais, componentes reais de uma situação opressora. Mas a tomada de consciência ainda não é a conscientização. Esta dependerá da práxis, da ação-reflexão-ação do sujeito que decide modificar sua atuação no mundo.

Sob a ótica freireana, a educação libertadora é utopia, mas não como algo irrealizável, um sonho que se persegue e nunca se alcança. Utopia para Freire é compromisso para com a história dos homens (e das mulheres), e os que nela se envolvem a partir do campo educativo buscam uma educação que conscientiza para a justiça social e se põem a anunciar o que humaniza e a denunciar o que desumaniza. Utopia "é compromisso histórico [...] exige o conhecimento crítico" (FREIRE, 2005b p. 32-33). É práxis, é ação-reflexão sobre o mundo, buscando transformar a injustiça em justiça. Para Freire, os pobres são os oprimidos, 
aqueles que são vítimas da situação desumanizante da sociedade, os que são coisificados, e a saída para estes é buscar "recuperar sua humanidade e sua libertação das contradições sociais" (MEDEIROS, 2013, p. 129). Porém, essa libertação demanda os mesmos oprimidos reconhecerem a situação de opressão em que vivem e lutarem contra ela.

Não é exigência freireana que alguém esteja completamente liberto para se empenhar na libertação dos outros. O necessário é sua consciência crítica que o faz optar por lutar pela libertação, dele e do outro, ainda que estejam em situações diferentes. Para Freire, não existe um "estar pronto", pois é próprio do humano ser inacabado, e mais, "somente podem ser proféticos os que anunciam e denunciam comprometidos permanentemente num processo radical de transformação do mundo" (FREIRE 2005b, p. 32).

Para Freire, ninguém pode conscientizar o outro, a conscientização é um processo de autonomia, mas uma autonomia entendida não como isolada, mas comunitária, solidária. A solidariedade está implícita na teoria da ação dialógica freireana, onde os homens são sujeitos que se encontram para "pronunciar" o mundo a fim de que esse seja transformado. Somente em intersubjetividade, em intercomunicação, os homens transformam o mundo e a real liderança, testemunha de solidariedade, é humilde e tem profunda fé nos homens (e nas mulheres).

\section{A bUSCA POR NOVOS CAMINHOS}

Mudar a sociedade ou a igreja não era a pretensão dos primeiros monges católicos. Eles não desejaram fazer um mundo diferente ou reformar a Igreja, quiseram apenas ser diferentes e distintos. Dessa forma, a intuição original e fundamental da vida religiosa não foi um projeto apostólico, mas um projeto ascético. O que eles quiseram foi mudar a si mesmos, buscando ser mulheres e homens capazes de viver de outro modo. Conceberam que o problema não estava em melhorar o que já existia, mas em apresentar uma forma de viver diferente daquela tida "normal", uma alternativa de viver frente ao Sistema estabelecido. A proposta era romper. Aqueles homens perceberam que o que não se rompe, se integra e o que se integra termina por aceitar as regras do jogo da "ordem presente".

Sob a ótica de Castillo (2004), para muitos religiosos hoje, para ter influência na sociedade e na igreja é preciso fazer. Dessa visão, nasce a ideia de que não há saída senão a integração ao Sistema de sociedade em que se vive. Dentro dessa lógica, a eficácia do que é feito nas instituições sociais e nas obras apostólicas está intrinsecamente condicionada a se viver dentro do sistema econômico estabelecido, com suas regras, seus interesses, suas contradições. A eficácia tem um preço muito alto e esse preço consiste no fato de que se torna praticamente impossível ser alternativa ao Sistema. Então, a única alternativa é serem reformistas, isto é, melhorar o que existe nesse Sistema. Essa contradição vem desde a Alta Idade Média, quando os mosteiros consideraram que, para manterem a fidelidade às suas normas e costumes, precisavam construir grandes conventos, grandes templos, ter grandes propriedades para ter influência sobre os grandes do mundo (até mesmo para cristianizá- 
-los). Isso pôs em risco a originalidade primitiva da vida religiosa. A pobreza permaneceu pessoal, mas não institucional. A situação se manteve por séculos. Os condicionamentos econômicos e sociais não só permitiam, como até o requeriam. No passado não muito distante, a sociedade ainda dependia de escolas, hospitais, obras de beneficência e outras formas de ajuda que as instituições públicas não forneciam à população. Hoje, de certa forma e em boa medida, nos espaços em que esses serviços já estão sendo assegurados, na visão de Castillo (2004), cada vez faz menos falta que sejam os religiosos que desempenhem determinadas atividades nas quais, no passado, já foram protagonistas sociais. Na visão do autor, a vida religiosa deveria ter condições de oferecer aquilo que hoje a sociedade carece: pessoas diferentes, que vivam valores alternativos e que pensem de modo distinto daqueles que se acomodam à forma de viver que lhes é imposta pela sociedade. No pensar do autor, os religiosos poderiam oferecer à sociedade um modelo de liberdade que rompesse com o sistema econômico, com suas necessidades e comodidades. A atitude profética presente nessa visão não consiste, basicamente, em denunciar e protestar, mas em viver de tal modo que a vida se converta em protesto e denúncia.

Para os primeiros monges, $\mathrm{o}$ simples desejo de ter dinheiro para atender às necessidades mais elementares da vida era algo tão detestável que consideravam isso "a raiz de todos os males", a tal ponto de se poder dizer que "o monge que possui muitas coisas é como um navio carregado com tanto peso, que acaba por afundar-se" (NILO DE CONSTANTINOPLA apud CASTILLO 2004, p. 102). Trabalhavam primordialmente para se alimentar e satisfazer suas necessidades básicas.

A pobreza social é um mal, uma desgraça e causa de insuportáveis sofrimentos para milhões de seres humanos. Isso leva à dificuldade do entendimento do voto de pobreza. Ele parece não fazer sentido. Na cultura atual, certamente faria mais sentido falar de um voto de solidariedade com os pobres e excluídos do que em voto de pobreza. As ideias de Castillo parecem não estar em consonância com as de Dussel e Freire, em relação ao posicionamento sociopolítico dos religiosos. Para o jesuíta espanhol, estes devem afastar-se do Sistema, para Dussel e Freire, se deve lutar contra o Sistema.

Talvez a figura do profeta possa nos dar um "sul"» mais claro. Tanto a Bíblia, fonte de inspiração para qualquer religioso cristão, quanto Dussel e Freire, apontam para a figura do profeta como expoente de libertação. Já dissera Dussel que para o semita a pobreza era condição de vida de um judeu autêntico que, diante do domínio do Império Romano, vivia honestamente de suas cabras, de suas oliveiras, de seus trabalhos manuais. Essa maneira de ver e viver a pobreza como condição de vida se aproxima do voto de pobreza do religioso

4 Parece muito estranho que se possa dizer que alguém aponte para o sul e não o norte como sinal de lugar "certo", destino "certo". Armado de Melo Lisboa, em seu artigo De América a Abya Yala - Semiótica da descolonização, faz um diálogo diante da relação feita entre América do Sul e Sul da Europa, contrapondo com a América do Norte e a Europa Teutônica. No início do século XIX, brotou a ideia de que a América do Sul era Latina. Esse era um tempo de expansão da hegemonia saxônica e eslava diante de ibéricos e italianos e passaram a ser considerados pelos do "Norte" como decadentes. A América do Norte e Europa Teutônica passaram a dominar o mundo ocidental. Em consequência, no "Sul" do ocidente, estarão os dominados. Assim, fazer referência ao "sul" e não ao "norte" como "destino certo" é uma forma de resistência ao colonialismo. 
que busca ter somente o necessário para viver. Mas é fundamentalmente na ação, no trabalho contra a miséria que existe em nossas cidades hoje - onde vivem aqueles que o Sistema exclui, aqueles que vivem sem trabalho, sem segurança, sem habitação - que o(a) profeta empenha sua vida. A pobreza (talvez melhor seria dizer miséria) contra a qual luta o profeta é anti-humana e nada tem a ver com a pobreza de uma vida "modesta". Os que põem à margem os miseráveis são aqueles de "espírito burguês" que vivem como os parasitas sociais.

Mas Dussel também traz o pobre de Iahweh como aquele que rompe com o sistema e, conscientemente, passa a viver como pobre. Esse abre mão de todo o comodismo de uma vida estável, às vezes escravizadora, e opta conscientemente pelos que pouco ou nada têm, para que estes não caiam na desesperança. O Servo também "suja" suas mãos para trabalhar contra a pobreza que impede a dignidade humana, atitude oposta às mãos "limpas" de Pilatos, que "fecha os olhos" e se exime de toda e qualquer responsabilidade.

Castillo (2004) diz que os monges fugiam para o deserto em busca de purificação, de santificação pessoal, de fuga do mundo. Dussel, por sua vez, faz sua interpretação do ponto de vista ético-teológico partindo de uma antropologia teologal e abordando a questão do mal, do demônio e do pecado. O mal do mundo do qual os monges fugiam é esse mal que Dussel parece encorajar a que seja enfrentado. Em sua interpretação, Dussel toma a oração do Pai Nosso: "Pai nosso... livra-nos do Maligno" (Mt 6,9-13). Essa passagem também poderia ser traduzida como: "não nos deixe cair em tentação", ou melhor ainda, "não nos deixe cair no mal" ou até mesmo, o que ele considera ser ainda melhor, "afasta o maligno" [de nós] (DUSSEL, 1985a, p. 11). Ele identifica o mal como sendo o demônio. Para Dussel, o mal não é algo privado, que alguém comete sozinho, e sim algo que se faz de forma coletiva. O autor fala também sobre o "príncipe deste mundo", que também é o demônio, e que "tudo organiza para seu domínio" (DUSSEL, 1985a, p. 11). Sob o ponto de vista dusseliano, o "príncipe deste mundo" pode ser representado por potências mundiais, que mantêm no mundo uma ordem, a qual aparenta justiça e paz, que usa a bandeira da segurança e se fundamenta na lei. O pobre oprimido é o protagonista da afirmação: "morreu sob Pôncio Pilatos". Quem morre é o justo sob o pecado do sistema político-religioso de seu tempo.

A Igreja Católica professa que Jesus era o Filho de Deus. Então, subentende-se que aceite que seja dito que o Sistema matou o Filho de Deus. Segundo Dussel (1985a, p. 20), "a dominação do homem pelo homem é o único pecado que o homem pode cometer". Na visão do autor, dominar o outro é reduzi-lo a servo, é aniquilá-lo. No credo Católico, Pilatos representa a totalidade romana, era ele o representante romano em Israel, um centro fechado sobre si mesmo. Para Dussel, o grande mal é a divinização da ordem e diz: "Hitler dizia 'Deus está conosco' (Gott ist mit uns) [...]. Na nota de um dólar lê-se: Nossa Confiança está em Deus" (DUSSEL, 1985a, p. 21). São duas faces da mesma moeda.

Dussel (1985b) apresenta ainda uma posição diversa daquela que pensa que as religiosas $^{5}$ devam ser pobres para atingir os pobres, como vetor para conquistar um espaço

Trazer o termo religiosas ao invés de religiosos remete ao pensamento dusseliano. Dussel ressalta mulher consagrada não como alguém que seja "virtuosa" no sentido grego do termo, como alguém que tem um corpo sem "mancha", mas aquela que abre mão de uma maternidade física real, que com liberdade reconhece as consequências de um profetismo itinerante. Dussel ressalta a mulher "não como mera "virtude de pureza", mas uma consagração a uma arriscada atitude profética” (DUSSEL, 1985, p. 117). 
social perdido. Ele se opõe a esse pensamento e afirma que "Jesus exige a pobreza como condição apostólica (Mt 10,1-42) e não, principalmente, como um conselho evangélico visando a perfeição pessoal" (DUSSEL, 1985b, p. 37). Jesus aconselhou seus discípulos a viverem na extrema pobreza não para se santificarem, mas para que ficasse muito clara a "Boa Nova" que pregavam.

Dussel (1985a) apresenta três sentidos de pobre, três "dimensões" de pobreza, relacionando-a ao cristianismo em suas origens. Em primeiro lugar, pobre é o oprimido enquanto oprimido. O autor aponta que Jesus assume a posição de oprimido, sendo Ele "um homem do 'povo da terra' [...], 'Como pode saber tantas coisas se não teve mestres?', objetam os que o desprezam” (DUSSEL, 1985a, p. 40). Em segundo lugar, pobre é o profeta, aquele que fala à Totalidade como testemunha de uma Nova Ordem, tornando-se sinal de contradição para a ordem dominante, e que por essa razão, é morto. O Sistema o mata, assim como matou todos os mártires que foram testemunhas da ordem que se opõe àquela que é hegemônica. Jesus também morreu mártir. O terceiro sentido de pobre é o "Servo de Javé", aquele que trabalha pela libertação do pobre. "Este pobre é uma terceira significação de pobre: o pobre exterior ao sistema" (DUSSEL, 1985a, p. 43; grifo do original), aquele que está consciente de que está fora do sistema que o exclui. Essa é a dimensão em que o Servo é o Libertador, aquele que tem uma práxis libertadora do pobre, o que trabalha em favor deste. A libertação do pobre oprimido é o foco central do Servo Libertador. A mudança do mundo pela transformação das pessoas pode ser vista, sob o olhar de Dussel, no Servo como alguém que nasce, vive e morre como pobre, assim como Jesus, o protótipo de Servo: "[Ele] foi simplesmente um pobre, um membro do povo da terra: um judeu, trabalhador manual de um esquecido do pobre povo de Israel" (DUSSEL, 1985b, p. 33; grifos do original).

$\mathrm{Na}$ interpretação teológica dusseliana, o pobre é o que está fora do sistema e anseia por uma ordem futura, uma ordem que, no pensamento semita, corresponde ao "Reino dos Céus", enquanto os que estão bem instalados e o excluem pertencem ao reino do presente, isto é, o "Reino que está na terra" e por isso esta é uma visão escatológica. Isso não significa dizer que essa nova ordem não possa acontecer na vida terrena. Dussel, fazendo alusão ao Evangelho narrado pelo Evangelista João, diz que o nascimento de Jesus é a manifestação de Deus na história dos homens, a irrupção dentro da carne humana que, ao nascer, "interpelará na e diante da carne e do sistema, todos os pobres do mundo" (DUSSEL, 1985a, p. 39).

Sob o olhar de Freire, ser sujeito da História e não objeto de outros é a condição ontológica do homem. A humanização da pessoa é sua vocação ontológica. Freire usa termos como: desumanização, opressão, negação do diálogo, domesticação, coisificação. A proposta freireana aponta para uma educação libertadora como caminho para a superação daquilo que impede que o homem seja homem, no sentido de realização de sua condição ontológica de transcender-se, visto ser inacabado. Manipular para dominar e dividir para manter a opressão é atitude similar àqueles que levaram Jesus de Nazaré a Pilatos, o representante da ordem que, ao "lavar suas mãos", abriu as portas aos que divinizavam César, a personificação do Sistema. "Daí pois, a César o que é de César” (Mt 22,21). Reduzir a 
condição do homem a objeto que mantém em funcionamento as engrenagens do Sistema é dar condição para que este Sistema seja conduzido de homem a homem. O homem "liberto da opressão", sob a ótica freireana e a visão dusseliana, é aquele capaz de frear as engrenagens que impedem que o homem viva sua condição de homem, libertação sempre vista em processo.

Dentro desse contexto em que se fala em pecado e pecaminosidade, Dussel faz sua interpretação sobre o Pecado Original. Para ele, o pecado dito como "original" é herdado porque "se transmite pela constituição ontológica do ser no processo educativo" (DUSSEL, 1985a, p. 33). O pecado do mundo é o pecado da carne e este é transmitido por meio da educação cultural. "'Pai nosso... livra-nos do maligno [...]' 'não nos deixeis cair em tentação’! Esta é a questão. Livra-nos de sermos solidários com o Príncipe deste mundo, de entrar com consciência e vontade nas estruturas que dominam o homem" (DUSSEL, 1985a, p. 33; grifos do original). Livra-nos de lavarmos as mãos à banalidade do mal. ${ }^{6}$ Segundo Dussel, a justificativa para a morte de Jesus pelos representantes romanos e líderes judeus estava na convicção destes mandatários de que eles eram os representantes de Deus. A Ordem havia sido divinizada por eles. Jesus e os profetas mártires que o seguiram morreram porque eram ateus dos deuses romanos e não adoravam a totalidade romana, o imperador. Hoje ainda, o Sistema persegue e mata quem se opõe a ele. Dussel, citando o papa João Paulo II, no dia 21 de fevereiro de 1979, durante a Conferência de Puebla, quando falava de injustiças sociais, denunciando o que fere o homem em sua dignidade:

\begin{abstract}
Devemos por seu nome a qualquer injustiça social, qualquer discriminação, qualquer violência infligida ao homem e seu corpo, espírito, consciência, dignidade humana e sua vida. Devemos chamar por seu nome à injustiça, à exploração do homem pelo homem e à exploração do homem por parte do Estado e dos sistemas econômicos (PAPA JOÃO PAULO II, 1979 apud DUSSEL 1984a, p. 125).
\end{abstract}

Em Freire (2005b, p. 44; grifo do autor), o homem é "fazedor de história". Um homem (ou uma mulher) faz história quando capta os grandes temas de sua época e se compromete com ela, descruzando seus braços e nela agindo, ao invés de deixar-se arrastar por ela. Para tanto, ele precisa conscientizar-se da realidade em que vive e acreditar em sua capacidade de transformá-la. Se assim não for, não será um ser ativamente participante. Assim sendo, toda e qualquer ação educativa terá como objetivo primeiro "provocar uma atitude crítica, de reflexão, que comprometa a ação" (IDOC Internacional, 1970 apud FREIRE, 2005b, p. 46).

$\mathrm{O}$ educador que leva a leitura crítica da realidade à luz da pedagogia freireana corresponde ao profeta dusseliano que nasce do meio do povo e está comprometido integralmente

6 O termo Mal Banal é desenvolvido pela filósofa judia Hannah Arendt, que o associa ao "vazio de pensamento", a renúncia à capacidade de julgar e pensar. São males cometidos pelos homens sem qualquer motivo, convicção, razão maligna ou intenção demoníaca. Arendt desenvolve esse conceito depois que participa em Jerusalém do julgamento de Adolf Eichmann, em 1961, pelos crimes cometidos contra os judeus durante a Segunda Guerra Mundial e a forma como ele reage, alegando não ter culpa alguma dos males que cometeu, porque apenas cumpria ordens. 
com a vida do povo. Ser perfeito, ser profeta, é viver em comunidade, é estar presente na História e, de acordo com a libertação dusseliana, o profeta só se considera salvo, num sentido bíblico, junto aos seus irmãos e irmãs. Para ele, a relação com a subjetividade do outro é intrínseca à sua vida. Para Dussel (1984a, p. 45), a "intersubjetividade [é] condição de perfeição para o semita". Para o judeu, ninguém se salva sozinho, contemplando o divino, como diziam os pensadores gregos, mas em comunidade. O homem só se salva na intersubjetividade. Para Freire, a conscientização só pode ocorrer na pronúncia coletiva do mundo. Sob a ótica semita, "um homem que, na comunidade, se compromete com a história, este é o profeta" (DUSSEL, 1984a, p. 46). Para o escritor argentino, o profeta dá a vida pela libertação dos pobres e dos oprimidos.

\begin{abstract}
A história é para o homem o ponto de partida da salvação. O profeta é o homem perfeito para o povo de Israel. Isso ocorre porque o profeta é o que descobre o sentido da história e este sentido é pensado e proclamado ao povo. O que o profeta lhe grita é o sentido da história, o sentido que Deus tem na história do homem. O profeta proclama o sentido do presente histórico (DUSSEL, 1984a, p. 46-47).
\end{abstract}

Cada um dos autores citados expressa, a seu modo, um jeito de combater a pobreza e as injustiças sociais. A questão está no modus operandi, na forma como se denuncia e anuncia. Opor-se ao sistema capitalista pelo testemunho profético é uma alternativa, como foi para os monges do deserto no Egito. Se me oponho ao Sistema que mata, não posso alimentá-lo. Se me oponho às estruturas que matam a vida, tenho que agir como o educador freireano e como o profeta libertador dusseliano. Como ser um profeta que age de forma autêntica, se eu consumo produtos de grandes empresas que usam mão de obra escrava, de empresas que são de propriedade de pessoas corruptas, se fecho os olhos para tantos problemas sociais, se ignoro o sofrimento de tantos irmãos, se não cuido do planeta?

No entanto, combater o capitalismo negando-se a alimentá-lo não é suficiente. É preciso combatê-lo. Nos últimos anos, a Congregação das IENS tem crescido neste requisito. "Estamos convencidas [...] de que a educação é a nossa resposta aos gritos da Criação, expressão concreta de nossa solidariedade com todos. Por isso, promovemos educação para todas as pessoas, especialmente, as que são marginalizadas e esquecidas" (IENS, 2007).

A solidariedade está implícita na teoria da ação dialógica freireana, onde os homens, em colaboração, transformam o mundo. Os homens são "sujeitos que se encontram para a pronúncia do mundo para sua transformação" (FREIRE, 2014, p. 227). Para Freire, solidariedade é um elemento da educação crítica no caminho da conscientização. No ano de 2012, as IENS repostam em seus documentos:

[...] Nós nos comprometemos a: [...], viver de modo mais simples, responsável e sustentável [...], direcionar nossos recursos e ministérios para a educação que transforma e impele todos a eliminar as "causas fundamentais da injustiça". desenvolveremos mais e integraremos em nosso ministério, materiais e modelos que promovam a libertação das pessoas e diminuam a realidade de sua opressão. [...] desenvolvermos ações apropriadas para responder rapidamente 
a situações injustas. [...] apoiaremos pela nossa presença ativa, àqueles cujas vidas estão em perigo por causa de seu trabalho por justiça ou seu comprometimento com os empobrecidos (IENS, 2013).

Em 2016, as IENS redigiram um novo documento onde expressam metas e objetivos que desenvolverão na educação de novos membros. Esse documento resgata outro documento elaborado pela Vida Religiosa Consagrada Feminina Católica, subentendendo que toda a Vida Religiosa Feminina de Vida Ativa vem trabalhando em conjunto com foco nas questões sociais. Nesse documento formativo das IENS, se pode ler outros objetivos extraídos da União Internacional das Superioras Gerais e da União dos Superiores Gerais: "Descobrir a dimensão social da Fé e a relação que existe entre vida cristã e compromisso social" (JPIC da UISG e USG, p. 49 apud IENS, 2016, p. 14, n. 6). E também almeja tornar mais vital a oração como consciência da presença de Deus e da ação constante do Espírito na realidade mundial, comunitária e pessoal: "[...]. Assumir um estilo de vida simples, solidária e coerente com o compromisso em favor dos mais pobres" (JPIC apud IENS, 2016, p. 21).

É dessa forma, e sempre em processo, que a pobreza pode ser entendida como vocacional na IENS, presente em sua orientação formativa de novos membros e também em sua prática cotidiana. As reflexões de Dussel e Freire podem cruzar com as de Castillo, trazendo avanços no fazer de uma congregação - como de tantas outras - preocupada em manter-se viva a partir de sua necessidade histórica e de seu compromisso com os pobres, os oprimidos do sistema.

\section{CONSIDERaÇões FINAIS}

Respondendo à pergunta colocada inicialmente, de qual o sentido da pobreza para a IENS, primeiramente é necessário problematizar o porquê de os religiosos católicos combaterem a pobreza ao mesmo tempo em que optam por ela. Confirmo que esse direcionamento está sedimentado nos pilares da vida religiosa católica e está intrinsecamente ligado às origens da Congregação das Irmãs Escolares de Nossa Senhora, assim como para as congregações católicas. As origens da vida religiosa no deserto do Egito, movimento ocorrido no final do século III de nossa era, fundamentaram-se na insatisfação de algumas pessoas frente às "facilidades" da vida cristã na sociedade da época. Os primeiros monges buscaram outra forma de viver o cristianismo. Esses monges poderiam ter optado pelo seguimento da vida cristã onde viviam, pois não dependiam das riquezas e facilidades que poderiam ter. Mas isso não era suficiente para eles, pois rejeitavam o Sistema vigente e queriam opor-se a ele. Essa foi uma decisão radical, uma forma de enfrentamento.

Radical foi também aquele que deu origem ao cristianismo. Jesus de Nazaré viveu e conclamou outros a viverem de forma diferente. Contando parábolas, ensinando, enfrentou o Sistema. As bases do pensamento de Dussel e Freire remetem ao cristianismo. Dussel cita passagens bíblicas em seus escritos e Freire luta para que haja denúncia daquilo que oprime e marginaliza o homem [e a mulher]. Oprimir e marginalizar são formas de matar. 
Para Dussel, a pobreza está relacionada a questões sociais profundas. O autor critica a submissão teórica da América Latina à filosofia e à epistemologia europeia e estadunidense. Seus escritos falam em libertação do domínio estrangeiro no continente latino-americano. Relacionando com o cristianismo, quem eram César e Pilatos? Eles não eram judeus, eram estrangeiros. Pilatos estava em Israel, representando o Império Romano.

Representante estrangeiro também foi Colombo. O que buscava Colombo? Riquezas para os reis ibéricos. Foi a partir do domínio estrangeiro que nossos índios foram "criados". A vida dos povos latino-americanos frente à história europeia não "existiu", pois se julga que foram os europeus que "descobriram" a América. Eles descobriram e dominaram o continente latino. Assim como os romanos dominaram a pátria dos judeus, ignorando o que pensavam ou sentiam, assim foram os primeiros colonizadores europeus que aqui chegaram a partir do século XVI.

Dussel alerta que a dominação à América Latina do passado ainda persiste hoje. Continua a dominação cujas consequências são a desigual distribuição das riquezas e o vertiginoso crescimento da pobreza. Para o autor, a história concreta dos homens é um "lugar teológico" e cita o apelo de Deus a Moisés: "Eu vi a aflição do meu povo que está no Egito... conheço seus sofrimentos... envio-te ao faraó para tirar do Egito o povo de Israel” (Ex 3,7). Moisés, ao ser enviado, agiu. Agiu concretamente dentro da história real do povo judeu.

Freire dá pistas de como libertar o povo oprimido: levá-lo a conscientizar-se da realidade de opressão em que vive. Ele partilha a ideia de que o homem é um ser histórico e deve agir na História. Para tanto, precisa abrir-se para compreender a realidade em que vive de forma a poder agir sobre ela para transformá-la. A essa compreensão, Freire chama de "leitura do mundo". O autor afirma também que a existência humana deve "pronunciar o mundo" para poder transformá-lo, salientando que a ela está intrinsecamente ligado o diálogo. Na visão freireana, a educação é vista como via de libertação do homem daquilo que o oprime e o marginaliza socialmente. Nessa visão, a educação não é um ato neutro, é um ato político. Há uma intenção atrás do que é ensinado. Por certo que essa educação não é apenas formal, mas um modo como nos dirigimos e nos posicionamos socialmente, uma vez que, para o autor, ninguém educa ninguém, os homens têm um compromisso histórico uns com os outros e o diálogo leva à conscientização que conduz a transformação do mundo.

Para um religioso que vive a pobreza de forma consciente, de acordo com o pensar desse modo de vida, a pobreza não é masoquismo, nem sacrifício. É solidariedade. Assim como os primeiros monges se opuseram ao Sistema vigente da época, abrindo mão da estabilidade e da segurança que poderiam ter, assim é a opção pela pobreza dos religiosos.

No entanto, Dussel e Freire propõem um passo a mais: além de opor-se ao sistema, é preciso lutar contra ele. Uma forma eloquente de resposta é não seguir as regras do Sistema, não atender a seus comandos. O consumo está no centro do sistema capitalista e liberal que nos envolve. Sem consumo, ele não sobrevive. Para que serve o dinheiro se não para comprar e possuir? Negar-se ao consumo do que não é básico à sobrevivência é enfrentá-1o. Assim sendo, a pobreza como opção de vida é poderosa arma contra esse Sistema e uma maneira de solidariedade para com aqueles que vivem marginalizados e oprimidos 
socialmente. No entanto, não aceitar as regras estabelecidas pelo sistema, não é suficiente. É preciso combatê-lo. É preciso que os religiosos sejam solidários. Nos últimos anos, a vida religiosa consagrada católica tem alargado seu horizonte em relação a esse aspecto, e as Irmãs Escolares de Nossa Senhora fazem parte desse universo. Por meio das afirmações: "promovemos educação para todos [...], especialmente, as que são marginalizadas e esquecidas (IENS, 2007)", "direcionar nossos recursos e ministérios para a educação que transforma e impele todos a eliminar as "causas fundamentais da injustiça"”, "[...] apoiaremos pela nossa presença ativa, àqueles cujas vidas estão em perigo por causa de seu trabalho por justiça ou seu comprometimento com os empobrecidos" (IENS, 2013), denota compreensão do conceito de solidariedade e enfrentamento da pobreza consequente do feroz sistema capitalista, inaugurado em nossa terra pelos colonizadores europeus.

\section{REFERÊNCIAS}

ALVES, Claudenir Módolo. Ética da Libertação: A Vítima na Perspectiva Dusseliana. São Paulo: PUC, 2005. Dissertação (Pós-Graduação em Filosofia), Pontifícia Universidade Católica de São Paulo. Disponível em: http://www.sapientia.pucsp.br/tde_busca/arquivo. php?codArquivo=1547. Acesso em 2 fev. 2016.

BÍBLIA PASTORAL. Direção editorial e revisão exegética de Paulo Bazaglia. São Paulo: Paulus, 2014, 1.544p.

CADA Lawrence et al. Em busca de um futuro para a vida religiosa. Tradução de Christina Sturmmer. São Paulo: Paulinas, 1985, 261p.

CASELA, José Maria Santana. A utopia possível de Enrique Dussel: a arquitetônica da Ética da Libertação. Caselas, J. M. S. Cadernos de Ética e Filosofia Política 15, 2/2009, p. 63-84. Acesso em: 19 fev. 2019. Disponível em:

file:///C:/Users/lcstudent/Downloads/82608-Texto\%20do\%20artigo-114180-1-10-20140701.pdf. Acesso em: 19 fev. 2019.

CASTILLO, José M. O Futuro da Vida Religiosa: Das Origens à crise atual. Tradução de Pe. Adérito Lourenço Louro, SSP. São Paulo: Paulus, 2004, 222p.

DUSSEL, Enrique D. Filosofia da Libertação. Tradução de Luiz João Gaio. São Paulo: Loyola, 1977, 275p.

Caminhos de Libertação Latino-Americana: interpretação histórico teológica. Tradução de José Carlos Barcelos, Hugo Toschi; revisão de Carlos Vido. São Paulo: Paulinas, 1984 a, 152p. 
. Caminhos de Libertação Latino-Americana: história, colonialismo e libertação. Tradução de José Carlos Barcellos, Hugo Toschi; revisão de Carlos Vido. São Paulo: Paulinas, 1984 b, 226p.

. Caminhos de Libertação Latino-Americana: interpretação ético-teológica. Tradução de José Carlos Barcellos, Hugo Toschi; revisão de Carlos Vido. São Paulo: Paulinas, 1985, 180p.

1492: O Encobrimento do Outro - A origem do mito da modernidade: Conferências de Frankfurt. Tradução de Jaime A. Clasen. Petrópolis: Vozes, 1993, 196p. Disponível em: http://enriquedussel.com/DVD\%20Obras\%20Enrique\%20Dussel/Textos/35/1492. pdf.

Acesso em: 9 fev. 2016.

. Caminhos de Libertação Latino-Americana: interpretação ético-teológica. Tradução de José Carlos Barcellos, Hugo Toschi; revisão de Carlos Vido. São Paulo: Paulinas, 1985, 180p.

. Europa, Modernidade e Eurocentrismo. In: LANDER, Edgardo (Org.).

colonialidade do saber: eurocentrismo e ciências sociais. Perspectivas Latinoamericanas. Coleccion Sur Sur. Buenos Aires: CLACSO, 2005, p. 24-32.

FRANCO, José Eduardo. Das Ordens às Congregações Religiosas: Metamorfoses da Vida Consagrada Católica (Uma Perspectiva Histórica). Boletim do Núcleo Cultural da Horta, 16: 255-269. Lisboa, 2007.

www.nch.pt/biblioteca-virtual/bol-nch16/255-269_congregacoes-religiosas.pdf. Acesso em: 20 fev. 2019.

FREIRE, Paulo. Papel da Educação na Humanização. Resumo de palestras realizadas em 05-1967, em Santiago, sob o patrocínio da OEA, do Governo do Chile e da Universidade do Chile. Publicado originariamente em Revista Paz e Terra. São Paulo, n. 9, p. 123-132, out. 1969. Disponível em: https://pt.scribd.com/document/300526301/Freire-Paulo-1969-Papel-Da-Educacao-Na-Humanizacao. Acesso em: 5 dez. 2016.

. Conscientização: Teoria e Prática da Libertação, 3. ed. São Paulo: Centauro, 2005b, $116 \mathrm{p}$.

. A Importância do Ato de Ler: Em Três Artigos que se completam, 42. ed. São Paulo: Cortez, 2001, 87p.

. Pedagogia do Oprimido, 57. ed. Rio de Janeiro: Paz \& Terra, 2014, 254p. 
GOMES, Laurentino. 1808: Como uma rainha louca, um príncipe medroso e uma corte corrupta enganaram Napoleão e mudaram a história do Brasil e de Portugal, 3. ed. revisada e ampliada. Globo, 2014, 382p.

IENS. Vós Sois Enviadas: Constituição e Diretório Geral das Irmãs Escolares de Nossa Senhora. Canoas: La Salle, 1987, 120p.

outubro de 2007.

. Chamadas à Solidariedade - Direção Orientadora do $22^{\circ}$. Capítulo Geral, 24 de . O Amor Não Pode Esperar - Direção Orientadora do $23^{\circ}$. Capítulo Geral, 24 de outubro de 2012.

. Rede Shalom. Disponível em: https://gerhardinger.org/images/Shalom/Shalom_ Document/Shalomdoc 2013-Portuguese-June192013.pdf. Acesso em: 23 abr. 2017.

JOB, Franz Sebastian. O Espírito da Constituição do Instituto Religioso das Pobres Irmãs Escolares de Notre Dame para a Educação da Juventude Feminina. Tradução Irmã Maria Helena Arns. Porto Alegre: IENS [1833], [Aprovação Eclesiástica 1839],1985, 79p.

LISBOA, Armando de Melo. De América a Abya Yala: Semiótica da descolonização. Revista de Educação Pública, Cuiabá, v. 23, n. 53/2, p. 501-531, mai. /ago. 2014.

MEDEIROS, Alexsandro. Humanização Versus Desumanização: Reflexões em torno da Pedagogia do Oprimido. Revista Reflexões. Fortaleza, v. 2, n. 3, p. 27-137, jul./dez. 2013.

NELSON, Sally Ann et al. Madre Teresa, Mulher de Visão. Tradução de Tarcísia Schwade. Porto Alegre: Metrópole, 1979, 94p.

OLIVEIRA, Ivanilde Apoliceno; DIAS, Alder Sousa. Ética da Libertação de Enrique Dussel: caminho de superação do irracionalismo moderno e da exclusão social. Conjectura, v. 17, n. 3, p. 90-106, set./dez. 2012. Disponível em: 2012http://www.ucs.br/etc/revistas/ index.php/conjectura/article/download/1798/1129. Acesso em: 11 fev. 2019.

PUC Rio Certificação Digital n. 0812682; CA. A Teologia Latino-Americana da Libertação: nosso ponto de aproximação com a Teologia da Esperança de Jürgen. Disponível em: Moltmannhttps: /www.maxwell.vrac.puc-rio.br/19888/19888_5.PDF. Acesso em:15 fev. 2019.

SILVA, Cláudia Neves da. Igreja Católica, assistência social e caridade: aproximações e divergências. Sociologias, Porto Alegre, v. 8, n. 15, p. 326-351, jan. /jun. 2006. Disponível em: www.scielo.br/pdf/soc/n15/a12v8n15.pdf. Acesso em: 22 mai. 2017. 
WEFFORT, Francisco C. Reflexões Sociológicas sobre uma Pedagogia da Liberdade. In: FREIRE, Paulo. Educação como Prática de Liberdade, 28. ed. Rio de Janeiro: Paz e Terra, 2005 a, $158 \mathrm{p}$.

\section{DAdos Da AUTORA:}

\section{Mirian de Medeiros}

Graduada em Ciências Biológicas pela Universidade do Extremo Sul Catarinense. Especialista em Administração e Supervisão Escolar pela Pontifícia Universidade Católica do Paraná. Mestre em Educação pela Universidade do Extremo Sul Catarinense. Membro da Congregação das Irmãs Escolares de Nossa Senhora. Criciúma/SC - Brasil.mirian.iens@ yahoo.com.br

Submetido em: $15-12-2017$

Aceito em: 15-3-2019 